\title{
The efficiency of pig farming inputs in Minahasa Regency of North Sulawesi
}

\author{
N. M. Santa*, M.A.V. Manese and P.O.V. Waleleng \\ Faculty of Animal Husbandry, Sam Ratulangi University, \\ Jalan Kampus - Bahu, Manado 95115 - Indonesia \\ *Corresponding E-mail: nansisanta@unsrat.ac.id
}

Received October 04, 2020; Accepted November 26, 2020

\begin{abstract}
ABSTRAK
Tujuan penelitian yaitu untuk menganalisis faktor-faktor yang mempengaruhi produksi dan efisiensi penggunaan input pada usahatani ternak babi di Kabupaten Minahasa Propinsi Sulawesi Utara. Lokasi penelitian ditentukan menggunakan metode multistage random sampling yaitu penentuan kabupaten, kecamatan dan desa yang memiliki populasi ternak babi tertinggi di Propinsi Sulawesi Utara, sehingga terpilih Kabupaten Minahasa, selanjutnya Kecamatan Sonder, Kakas, Tombulu and Tombariri, dan masing-masing diambil 2 desa. Sampel ditentukan menggunakan metode acak sederhana dengan mengambil 25 peternak pada setiap kecamatan, sehingga total sampel sebanyak 100 peternak babi rakyat, selanjutnya pengambilan data dilaksanakan bulan Januari-Juli 2019. Variabel yang diukur adalah jumlah produksi, jumlah induk, jumlah anak babi, jumlah pakan (jagung, konsentrat, dedak padi) dan tenaga kerja. Analisis data menggunakan model fungsi produksi Cobb-Douglas dengan perhitungan regresi linier berganda dan nilai produk marjinal. Hasil penelitian menunjukkan bahwa efisiensi pada usahatani babi memiliki nilai lebih besar dari 1, sehingga tidak efisien. Kondisi tersebut masih memungkinkan bagi peternak untuk meningkatkan produksi ternaknya dengan menambah jumlah induk, jumlah anak babi, jumlah pakan (jagung, dedak padi, konsentrat), dan jumlah tenaga kerja.
\end{abstract}

Kata kunci : usahatani ternak babi, efisiensi, pakan, induk babi, anak babi

\begin{abstract}
The purpose of this study was to analyze the factors influencing the production and the efficiency of pig farming input in Minahasa Regency of North Sulawesi Province. The location was determined using the multistage random sampling method, determining regency, districts, and village, which have the highest pig population in North Sulawesi Province, so that Minahasa Regency, and four selected Districts (Sonder, Kakas, Tombulu and Tombariri), then 2 villages/district were taken. The sample was determined using a simple random method by taking 25 farmers in each district so that the total sample was 100 pig farmers, then the data was taken in January-July 2019. Variables measured were the number of pig production, the number of sows, the number of piglets, the number of feed (corn, concentrate, rice bran) and the number of labor. Data were analyzed using the Cobb-Douglas production function model with multiple linear regression and marginal product values calculations. The results showed that the efficiency of pig farming inputs was larger than one, meaning it was inefficient. This condition is still possible to increase pig production by increasing the number of sows, the number of piglets, the number of feed (corn, bran, concentrate), and the number of labor.
\end{abstract}

Keywords: pig farming, efficiency, feed, sows, piglets 


\section{INTRODUCTION}

Minahasa Regency of North Sulawesi Province has the highest number of pig population in 2018 (Central Bureau of Statistics of North Sulawesi, 2019). Pig farming models in rural communities were using a breeding model, fattening model, and a combination of breedingfattening model (Santa and Wantasen, 2018). The farming system management was still conducted under the traditional system, were commonly found in rural areas of Indonesia (Santa and Wantasen, 2018; Kalangi et al., 2016; Leslie et al., 2015; Iyai et al., 2013; Prasetyo et al., 2012; Iyai et al., 2011).

In doing business, farmers aim to increase the amount of production and profit from their business. However, to produce maximum output, pig farmers will use the smallest possible input. Efficiency can occur in two situations, firstly by using the same input, it can produce a large output, secondly, with a small input, it can produce the same output (Rasmussen, 2013). Pig farmers in Minahasa Regency use feed input, sows, piglets and labor. The feed given is a formulation of corn, rice bran, concentrate, and mineral, where each pig farmer has a different feed formulation based on the experience and information of the farmer's parents. These feed ingredients are generally purchased in animal feed stores, and only a few farmers use the produce of corn farming. This condition causes pig farmers to depend on the availability of the feed in feed stores, so that if there is an increase in feed prices, the pig farmers will reduce the number of pig feed. Based on observations and the results of previous studies, pigs were fed twice a day, in the morning and evening with an average of $2.5 \mathrm{~kg}$ of feed for each feed. According to Beyihayo et al., 2015, feed requirements for sows (Pregnant/lactating) were range from 2-3.5 $\mathrm{kg}$ /day. Feeding requirements for piglets at ages 8-12 weeks were $0.77-0.96 \mathrm{~kg} /$ day and ages $16-20$ weeks as much as $2.88-3.29 \mathrm{~kg} /$ day (Hi-Pro Pig Farmers Booklet, 2015). Excessive feeding without following the number of feed requirements will cause high feed costs and affecting the profits of pig farming.

The number of sows and piglets is an input factor that affects production. Sows usually give birth to 10-14 piglets for each birth (Beyihayo et al., 2015). Based on observations, pig farmers have 2 sows, with the number of piglets varying between 10-12 piglets/sow. If the ownership of the number of sows increased, the number of piglets and the production of pigs will also increase. This situation was in accordance with Soltész et al. (2013) which stated that the litter size and feed consumption of piglet greatly affects total income.

Several studies on the technical efficiency of livestock farming have been previously studied by Ekowati et al. (2018). Moreover, research in pig farming was done by Kojo et al. (2014), Adetunji and Adeyamo (2012). The research of Kojo et al., 2014 specialized on income and marginal product value of pig feed input, whereas feed was not the main factor that can affect the number of pig production, while Adetunji and Adeyamo (2012) stated that feed cost, stocking cost, and labor cost had a positive and significant effect on the economic efficiency of pig farming.

The purpose of this study was to analyze the factors that influence the production and input efficiency of pig farms. This study was different from previous studies, especially on the inputs used in the efficiency analysis. These inputs are production factors in pig farming, such as the number of sows, the number of piglets, the number of feed (corn, rice bran, concentrate), and labor. The results of this study are expected to provide information to pig farmers about how to increase the amount of pig production by using efficient amounts of input (feed, labor, and ownership of sows and piglets), to achieve maximum profit.

\section{MATERIALS AND METHODS}

\section{Sampling Methods and Data Collection}

The study was conducted by survey method in January-July 2019, using the multistage random sampling method as a sampling technique (Silalahi, 2015). There were four districts (Sonder, Tombulu, Kakas and Tombariri) that had the most pig population in the Minahasa Regency. Two villages were selected each district with the most pig farming located in Sonder District (Villages of Kauneran and Tonelet), Tombulu District (Villages of Kembes and Kamangta), Kakas District (Villages of Sendangan and Tonelet) and Tombariri District (Villages of Lolah 2 and East Lemoh). Respondents were randomly selected 25 pig farmers for each district, or 12-13 pig farmers for each village.

The data used were primary and secondary data. Primary data were obtained through filling out the questionnaire by survey method, with 
observed variables such as the number of production, the number of sows, the number of piglets, the average body weight of pigs, the number of feed (corn, rice bran, concentrate, minerals), the number of medicines, in two pig farming sytsem (breeding models and a combination of breeding-fattening models). Secondary data was obtained from the results of the publication of the statistical center through the website.

\section{Data Analysis}

Data were analyzed using the Cobb-Douglas production function and the ratio of marginal product value (MPV) to input price $(\mathrm{Px})$. It was calculated to obtain the level of efficiency of each factor of production, with measured variables (the number of pig production, the number of sows and piglets, the average body weight of pigs, the number of feed (corn, rice bran, concentrate, minerals), and the number of labor. The analysis model was:

$Y=\beta_{0} X_{1}^{\beta 1} X_{2}^{\beta 2} X_{3}{ }^{\beta 3} X_{4}{ }^{\beta 4} X_{5}{ }^{\beta 5} X_{6} \beta 6$

Furthermore, it was transformed into a logarithmic linear function, then the production function model can be formulated in the equation: $\ln Y=\ln \beta_{0}+\beta_{1} \ln X_{1}+\beta_{2} \ln X_{2}+\beta_{3} \ln X_{3}+\beta_{4} \ln X_{4}+$ $\beta_{5} \ln X_{5}+\beta_{6} \ln X_{6}+\mu$

Where:

$\mathrm{Y}=$ pig production $(\mathrm{kg} /$ period $)$

$\beta_{0}=$ constant

$\beta_{1 \ldots} \beta_{6}=$ variable regression coefficient

$\mathrm{X}_{1}=$ the number of sows $(\mathrm{kg} /$ period)

$\mathrm{X}_{2}=$ the number of piglets $(\mathrm{kg} /$ period $)$

$\mathrm{X}_{3}=$ the number of corn $(\mathrm{kg} /$ period $)$

$\mathrm{X}_{4}=$ the number of rice bran $(\mathrm{kg} /$ period $)$

$\mathrm{X}_{5}=$ the number of concentrate $(\mathrm{kg} /$ period $)$

$\mathrm{X}_{6}=$ the number of labor $(\mathrm{HOK} /$ period $)$

The data analysis used the Eviews 9.0 program. Hypothesis testing was done using the coefficient of determination, $F$ test and t-test, and the testing of classical assumptions. Based on the Cobb-Douglas function, the value of $\beta i$ was the elasticity of production of each factor of production. Production elasticity was expressed in three alternatives, such as $\beta \mathrm{i}>1$ (Increasing Return to Scale), $\beta \mathrm{i}=1$ (Constant Return to Scale), and $\beta \mathrm{i}<1$ (Decreasing Return to Scale). The MPV was calculated based on the following formula (Rasmussen, 2013),
MPVx $=$ Px, or

MPV is the marginal product value of an input and $\mathrm{Px}$ is the input price. If the use of input $\mathrm{X}$ is not efficient, the number of inputs used needs to be increased, then if the use of input $\mathrm{X}$ is inefficient, the number of inputs used needs to be reduced.

\section{RESULTS AND DISCUSSION}

\section{Characteristics of Pig Farmers in Minahasa Regency}

The characteristics of pig farmers were described in Table 1. There were $53 \%$ of pig farmers aged between 41-50 years old, with a junior high school education level, and farming experience of around 20 years. The average number of sows owned was 2 heads with 21.5 piglets or 10-11 piglets/sow. Type of pigs that were raised by farmers were the types of Hampshire, Large White and Duroc. Handling of sows and piglets was still done traditionally (Velazco et al., 2013), especially to mate sows and castration. The sows are naturally mated by hiring the boar, where farmers generally know the techniques of mating sows, from checking the status of estrus and determining the right time for the sows to mate.

\section{Factors that Affecting the Pig Production in Minahasa}

Factors affecting pig production in Minahasa Regency are presented on Table 2. while the regression equation was $\mathrm{Y}=-6.361+0.325 \mathrm{X}_{1}+0.732 \mathrm{X}_{2}+0.048 \mathrm{X}_{3}+$ $0.051 \mathrm{X}_{4}+0.048 \mathrm{X}_{5}+2.495 \mathrm{X}_{6}$

Based on the results on Table 2, the variable of the number of pig production was influenced by the number of sows, the number of piglets, the number of corns, the number of rice bran, the number of concentrates, and the number of labor $(\mathrm{P}<0.01)$. The R-Square value of $99.08 \%$ means that $99.08 \%$ of the variation of the number of pig production were affecting the number of sows, the number of piglets, the number of corns, the number of rice bran, the number of concentrates, and the number of labor, and the remaining of $0.92 \%$ were affecting by variations of other variables outside the model. The model was a goodness of fit, because it has been through testing of classical assumptions, especially the multicollinearity and autocorrelation test. 
Table 1. Characteristics of Pig Farming in Minahasa Regency

\begin{tabular}{lr}
\hline \multicolumn{1}{c}{ Description } & \multicolumn{1}{c}{$\mathrm{N}$} \\
\hline Number of Samples (n) & 100 \\
Age of farmer (\%) & \\
$<35$ years old & 3.00 \\
35-40 years old & 20.00 \\
41-50 years old & 53.00 \\
$\quad>50$ years old & 24.00 \\
Level of graduation (\%) & \\
Graduated from elementary school & 19.00 \\
$\quad$ Graduated from junior high school & 54.00 \\
$\quad$ Graduated from senior high school & 27.00 \\
Gender (\%) & \\
$\quad$ Male & 20.00 \\
$\quad$ Female & 80.00 \\
Farmers experience (years) & 20.00 \\
The number of sow (head) & 2.00 \\
The number of piglet (head) & 21.50 \\
The litter size (head) & 11.00 \\
Type of pig (\%) & \\
$\quad$ Hampshire & 37.60 \\
Chester white & 31.85 \\
Duroc & 30.55 \\
\hline
\end{tabular}

$\mathrm{N}$ : The number of data analyzed

Table 2. Results of Regression Analysis of Factors Affecting The Pig Production

\begin{tabular}{lc}
\hline \multicolumn{1}{c}{ Variable } & $\begin{array}{c}\text { Coefficient of } \\
\text { Regression }\end{array}$ \\
\hline The number of sows & $0.325^{* * *}$ \\
The number of piglets & $0.732^{* * *}$ \\
The number of corn & 0.048 \\
The number of rice bran & 0.051 \\
The number of concentrate & 0.048 \\
Labor & $2.4957^{* * *}$ \\
R-squared & 0.9908 \\
Adjusted R-squared & 0.9903 \\
F-statistic & 1685.773 \\
Durbin-Watson stat & 1.861338 \\
\hline$* * *=$ highly significantly different $(\mathrm{P}<0.01)$
\end{tabular}

\section{Efficient Use of Inputs in Pig Production}

The elasticity value of the input factors based on the regression analysis in Table 2 shows the return to scale (RTS) with the regression coefficient $\beta \mathrm{i}>1 \quad\left(\beta_{1}+\beta_{2}+\beta_{3}+\beta_{4}+\beta_{5}+\beta_{6}=3.701\right.$. These results indicate that pig farms in Minahasa Regency had an increasing return to scale (Rasmussen, 2013). This means that the addition of fixed input production in the long term will increase the production and profits of pig farming. This situation also occurs in cattle farming where 80 farmers were had an increasing return to scale, where farmers can increase the number of cattle to reduce production costs so that production efficiency can increase (Ekowati et al., 2018).

Rasmussen (2013) through equation (3) above, then compared with the results of MPV calculations and MPV and Px ratios in Table 3, the input such as the number of sows, the number of piglets had a ratio 3.386 and 1.496 or MPV/Px ratio $>1$. This means that the input such as the number of sows and the number of piglets is not efficient, and need to be increased.

The number of sows and piglets have the MPV/Px ratio $>1$, which means increasing the number of sows and piglets would increase the number of pig production. Both of these inputs are fixed inputs in pig farming. Like a production machine in a company as a fixed input to produce a good, the sow was a production machine in pig farming because it can give birth to a number of piglets, called litter size (Phengvilaysouk et al., 2017). According to Baxter et al., 2013, the litter size about 7-20 piglets. Besides being influenced by genetic factors, the litter size was also influenced by the quality of feed, the management of pregnant sows, and the management of mating sows (Phengvilaysouk et al., 2017). Increased sow number can increased pig production, with other factors also considered. The pig production was the multiplication between the weight gain and the number of pigs sold. The weight gain of pigs in Minahasa Regency ranges from $80-100$ $\mathrm{kg} / \mathrm{head}$, and the litter size ranges from 8-13 piglets. Even though the weight gain of pigs has reached an optimal level without being followed by the number of pigs sold, pig production has not reached the optimal levels. Based on interviews with pig farmers, litter size and weaning piglets must be greater than 10 piglets for profit. In fact, the number of piglets weaned were less than the litter size.

The number of pigs fattened and sold 
Table 3. The Ratio of Marginal Product Value (MPV) to Input Price (Px) on Pig Farming

\begin{tabular}{lrrrrrr}
\hline \multicolumn{1}{c}{ Production Factors } & $\begin{array}{c}\text { Average of } \\
\text { Input }\left(\mathrm{X}_{\mathrm{i}}\right)\end{array}$ & $\begin{array}{r}\text { Elasticity } \\
\left(\beta_{\mathrm{i})}\right.\end{array}$ & $\begin{array}{r}\text { Marginal Product } \\
\left.\mathrm{MP}=\left(\beta_{\mathrm{i}} \mathrm{x}\right) / \mathrm{X}_{\mathrm{i}}\right)\end{array}$ & $\begin{array}{c}\mathrm{MPV} \\
(\mathrm{MP} \times \mathrm{PY})\end{array}$ & $\begin{array}{c}\text { Input } \\
\text { Price }(\mathrm{Px})\end{array}$ & $\begin{array}{c}\mathrm{MPV} / \\
\mathrm{Px}\end{array}$ \\
\hline The number of sow & 2.040 & 0.325 & 338.630 & $16,931,529$ & $5,000,000$ & 3.386 \\
$\begin{array}{l}\text { The number of piglet } \\
\text { The number of corn }\end{array}$ & 21.650 & 0.732 & 71.817 & $3,590,873$ & $2,400,000$ & 1.496 \\
$\begin{array}{l}\text { The number of rice } \\
\text { bran }\end{array}$ & 1124.404 & 0.048 & 0.091 & 4,585 & 4,000 & 1.146 \\
$\begin{array}{l}\text { The number of } \\
\text { concentrate }\end{array}$ & 560.967 & 0.051 & 0.194 & 9,713 & 4,000 & 2.428 \\
$\begin{array}{l}\text { Labor } \\
\mathrm{Y}=2,123.5\end{array}$ & 562.634 & 0.048 & 0.281 & 14,082 & 8,000 & 1.760 \\
$\mathrm{PY}=50,000$ & 511.200 & 2.495 & 10.366 & 51,834 & 125,000 & 4.147 \\
\hline
\end{tabular}

depends on the weaning piglets. Based on Table 1, it is known that the litter size was 11 piglets, but this number was reduced during weaning due to the lack of handling when piglets were born. This situation was agrred to Munzhelele et al., (2017) that there were $50 \%$ of pig mortality that can occurred before weaning (within 3-5 days of birth), and $90 \%$ of pig mortality were occurred after weaning. Baxter et al., 2013 and RangstrupChristensen et al., 2018 said that early weaning can increase the piglet's mortality. Therefore, pig farmers must take care of piglets intensively 1-7 days after birth, and weaning piglets starting from 42 days after birth.

Farmers feed pigs in the form of a mixture of corn, rice bran, concentrates, and minerals. Based on the results of the regression analysis in table 2 the number of corn, rice bran, and concentrate had a positive effect on pig production, while the number of rice bran had a positive effect, even though the effect was not significant $(\mathrm{P}>0.001)$. However, the feed efficiency of corn, rice bran and concentrate had a ratio $1.146 ; 2.428 ; 1.760$ or MPV/Px ratio $>1$, which means that the input was not efficient, and still need to be added. Based on the results of the study, pigs were fed two times per day in the morning and evening. The feed provided from a mixture of corn, rice bran, concentrate and minerals, with different compositions for each farmer. Farmers buy corn, rice bran, concentrates and minerals, then mix themselves into pig feed. The situation was very different from feeding broilers, where in each growth phase, broilers have been provided with commercial feed, so farmers can directly give it to broilers. Pig weight gain was influenced by genetic factors, feed quality and feeding management. Based on Table 1 there were 3 types of pigs in Minahasa Regency, such as Hampshire $(37.60 \%)$, Chester white $(31.85 \%)$ and Duroc (30.55\%). According to Choy et al., (2015), the three types of pigs have genetically had good productivity. However, genetic factors for pigs must also be followed by quality of feeding management. Pig farmers need more knowledge related to the management of feeding practices, to obtain maximum for pigs weight gain (Sanannam et al., 2014; Remus et al., 2019). The results showed that farmers did not know the protein needed to be fulfilled in the preparation of pig feed. In addition to the number of pig feed, it was different for each area. Pigs that were raised at low temperatures, will eat more than pigs that were raised at high temperatures (Cervantes et al., 2018; Ribeiro et al., 2018). In this situation, farmers' skills were needed to be improved to feeding practices and the composition of feed nutrition, hence that they will be able to provide better feeding management. Minahasa Regency was a mountainous area, which had a low temperature which caused a high level of feed consumption by pigs. The recommendation for pig farmers that feed is given with lower protein content, because pigs will consume more feed due to its response to lower temperatures. Concentrated feed needs to be reduced in pig 
feed.

Labor was a variable that had a positive and significant effect on the number of production ( $\mathrm{P}$ $<0.001$ ). Based on table $2 \mathrm{MPV}$ ratio of 4.147 or MPV $>1$, meaning that the allocation of working time on pig farming can still be added to increase the number of production. The allocation of time to work on pig farms was 1-2 hours per day by feeding the pigs, washing/cleaning the cage and washing the pigs. There are certain times when breeders allocate more time to handle and assist sows during calving and castrate the pigs.

Moreover, there were $80 \%$ of women or farmer's wives who help to work in pig farming and $20 \%$ of farmers were the head of the household. This situation was different from Mbuza et al., 2016 that $85 \%$ of pig farmers were male. The farmer's wife feds bathed the pigs and cleaned the cage every morning and evening. She mixed the feed once a week, handled sows that give birth, castrated, cut teeth and tails, were done by herself. Based on the interview, raising pigs was done by the farmer's wife as a side activity, because it only takes 1-2 hours/day. Almost all the cages were located behind the house, so the farmer's wife can easily reach them. The head of the family does not take care of the pigs because they have other main jobs. Pig farming was a side business because the allocation of time needed to raise pigs was only a small number, so farmers are more likely to work on other farms that require more time to work. The results of the analysis in table 3 show that the allocation of working time in pig farming needs to be increased hence pig farming productivity can be increased.

Based on the research, the management of sows and piglets played an important role in successful pig farming (Munzhelele et al., 2016). So that the number of piglets born was the same as the number of piglets that are weaned, the farmer needs to carry out more intensive handling of the piglets. Furthermore, farmers must get more knowledge about the eating behavior of pigs, due to the environmental factors that greatly affect the feeding consumption. Increasing the allocation of working time in pig farming must also be followed by an increase of knowledge and skills of farmers in raising pigs. Hence, feeding management can be improved to get maximum production and profit.

\section{CONCLUSION}

To increase pig production, farmers need to increase the number of sows and piglets and labor. The management of sows and piglets determined efficiency. Pig farmers need to reduce the number of concentrates in feed and increase the number of corns in feed to achieve efficiency.

\section{REFERENCES}

Adetunji, M.O. and K.E. Adeyemo. 2012. Economic efficiency of pig production in Oyo State, Nigeria, A Stochastic Production Frontier Approach. Am. J. Exp. Agric. 2(3): 382-394.

Baxter, E.M., K.M.D. Rutherford., R.B. D'Eath, G. Arnott, S.P. Turner, P. Sandøe, V.A Moustsen, F. Thorup, S.A. Edwards and A.B. Lawrence. 2013. The welfare implications of large litter size in the domestic pig II: management factors. An. Welf. 22:219-238.

Beyihayo, G., R. Mwesigwa and D. Pezo. 2015. Pig Feeding Strategies; Uganda Smallholder Pig Value Chain Capacity Development Training Manual. ILRI Manual 16. Nairobi, Kenya: Int. Livest. Res. Inst.

Cervantes, M., D.Antoine, J.A.Valle., N.Vásquez, R.L. Camacho, H.Bernal and A. Morales. 2018. Effect of feed intake level on the body temperature of pigs exposed to heat stress conditions. J. Thermal Biology. 76:1-7.

Choy, Y. H., A.Mahboob, C.I. Cho, J.G. Choi, I.S. Choi, T.J. Choi, K.H. Cho and B.H. Park. 2015. Genetic Parameters of Pre-adjusted Body Weight Growth and Ultrasound Measures of Body Tissue Development in Three Seedstock Pig Breed Populations in Korea. Asian-Australas J. Anim. Sci. 28(12): 1696-1702.

Ekowati, T., E. Prasetyo and M. Handayani. 2018. The Factors Influencing Production and Economic Efficiency of Beef Cattle Farm in Grobogan Region, Central Java. J. Indonesian Trop. Anim. Agric 43(1):76-84.

Hi-Pro Pig Farmers Booklet. 2015. Pig Management and Feeding Guide. Hi-Pro Feeds.

Iyai, D.A., B.W.I. Rahayu. I. Sumpe and D. Saragih. 2011. Analysis of Pig Profil on Small-Scale Pig Farmers in Manokwari, West Papua. J. Indonesian Trop. Anim. Agric. 36:190-197

Iyai, DA., O. Marani, T. Marjen and L. Usior. 2013. Pig Farming Performances of Three papuan tribes: case study of byak, onate and 
arfak tribes in papua barat. J. Indonesian Trop. Anim. Agric. 38(1):55-64.

Kalangi, L.S, Y. Syaukat, S.U. Kuntjoro and A. Priyanti. 2016. Factors affecting profit analysis of beef cattle farming in East Java, Indonesia. Livest. Res. Rural Dev. 28(12):Article\#226.

Kojo, R.E., V.V.J. Panelewen, M.A.V. Manese and N.M. Santa. 2014. Efisiensi Penggunaan Input Pakan dan Keuntungan Pada Usaha Ternak Babi di Kecamatan Tareran Kabupaten Minahasa Selatan. Zootec. 34(1):62-74.

Leslie, E. E. C., M. Geong, M. Abdurrahman, M. P. Ward and J.L.M.L. Toribio. 2015. A description of smallholder pig production systems in eastern Indonesia. Prev. Vet. Med. 118(4):319-327.

Mbuza, F., D. Majyambere, J.D.D. Ayabagabao and M.F. Dutuze. 2016. Inventory of pig production systems in Rwanda. Int. J. Livest. Prod. 7(7):41-47.

Munzhelele, P., J. Oguttu, O. G. Fasanmi and F. O. Fasina. 2017. Production constraints of smallholder pig farms in agro-ecological zones of Mpumalanga, South Africa. Trop. Anim. Health Prod. 49:63-69.

Munzhelele, P., J. Oguttu and F. O. Fasina. 2016. Is a 10 -sow unit economically sustainable? A profitability assessment of productivity amongst small-holder pig farmers, Mpumalanga, South Africa. Onderstepoort J. Vet. Res. 83(1).

Phengvilaysouk A, A. Jansson, P. Phengsavanh, T. Tiemann, V. Phengvichith and J.E. Lindberg 2017. Sow and piglet management in smallholder and larger-scale pig farms in Northern part of Laos. Livest. Res. Rural Dev. 29(10) Article \#201.

Rangstrup-Christensen, L., M. A. Krogh, L. J. Pedersen and J. T. Sørensen. 2018. Sow level risk factors for early piglet mortality and crushing in organic outdoor production. Animal. 12(4):810-818.

Rasmussen, S. 2013. Production Economics; The Basic Theory of Production Optimisation. Springer, Berlin, Heidelberg.

Remus, A., L. Hauschild, E. Corrent, M. L. Montminy and C. Pomar. 2019. Pigs receiving daily tailored diets using precisionfeeding techniques have different threonine requirements than pigs fed in conventional phase-feeding systems. J. Anim. Sci Biotechnol. 10(16).

Ribeiro, B.P. V. B., E. Lanferdini, J. Y. P. Palencia, M. A. G. Lemes, M. L. T. de Abreu, V. de S. Cantarelli and R. A. Ferreira. 2018. Heat negatively affects lactating swine: A metaanalysis. J. Thermal Biology. 74:325-330

Sanannam, A., K. Wuthijare A. Wanangkarn., W. Tochampa and T. Tartrakoon. 2014. Productivity of weaning-starter pigs fed fermented liquid feed. Naresuan Univ. J. Sci. Tech. 22(2):106-115

Santa, N.M. and E. Wantasen. 2018. Profit analysis of pig farming in rural comunities in minahasa regency of north Sulawesi. J. Indonesian Trop. Anim. Agric. 43(3):289295.

Sarajar, M.J., F.H. Elly, E. Wantasen and S.J.K. Umboh. 2019. Analisis usaha ternak babi di kecamatan sonder kabupaten minahasa. Zootec. 39(2):276-283.

Silalahi, U. 2015. Metode Penelitian Sosial Kuantitatif. Refika Aditama. Bandung

Soltész, A, S. Szőke and P. Balogh. 2013. Analysis of economic risks in sow production. J. Agric. Inform. 4(2):10-21.

Velazco, O. R. B., S. C. Sanz, F. E. Barber and A.V. García. 2013. Comparison of extensive and intensive pig production systems in Uruguay in terms of ethologic, physiologic and meat quality parameters. R. Bras. Zootec. 42(7):1-10. 